\title{
Pathological and Parasitological Findings in South American Fur Seal Pups (Arctocephalus australis) in Uruguay
}

\author{
Helena Katz, ${ }^{1}$ Diana Morgades, ${ }^{2}$ and Miguel Castro-Ramos ${ }^{3}$ \\ ${ }^{1}$ Área de Patología, Facultad de Veterinaria, Universidad de la República, Avenida Lasplaces 1550, 11600 Montevideo, Uruguay \\ ${ }^{2}$ Área de Parasitología, Facultad de Veterinaria, Universidad de la República, Avenida Lasplaces 1550, Montevideo, Uruguay \\ ${ }^{3}$ Laboratorio de Tuberculosis, División de Laboratorios Veterinarios "Miguel C. Rubino", Ministerio de Ganadería Agricultura y Pesca, \\ Ruta 8 km. 17,500, 12100 Montevideo, Uruguay \\ Correspondence should be addressed to Helena Katz, helekatz@gmail.com
}

Received 24 September 2012; Accepted 5 November 2012

Academic Editors: J. Ostner and U. Shanas

Copyright () 2012 Helena Katz et al. This is an open access article distributed under the Creative Commons Attribution License, which permits unrestricted use, distribution, and reproduction in any medium, provided the original work is properly cited.

This paper presents the necropsy findings in South American fur seal (Arctocephalus australis) pups from Uruguayan colonies. Animals $(n=105)$ were aged between 0 and 18 months old. From 0 to 6 months, $69.4 \%$ of the pups showed a poor body condition, while $68.8 \%$ of animals from 7 to 18 months had fair-to-good body condition. From 6 to 7 months of age, the stomach content included fishes, crustaceans, and foreign bodies. Starvation in the first months of life and traumatic lesions in pups older than 9 months were the most frequent causes of death. Uncinaria spp. was the only parasite found in the small intestine between 0 and 6 month-old pups. Parasites with indirect cycle (Contracaecum spp., Corynosoma sp., Tetrabothriidae) were present from 6 months of age as well as the first report of the nematode Strongyloides spp. in pinnipeds. Orthohalarachne spp. was found in the respiratory tract. Mycobacterium pinnipedii was isolated from 9 animals without gross pathological lesions. Other pathological conditions were found in lesser extent. This information contributes to the main causes of death of A. australis pups at different ages and could be useful to perform further health studies on this wild pinniped species.

\section{Introduction}

Parasitological and pathological studies have been useful in the study of wild ranging pinnipeds populations generating knowledge towards their conservation. Systematic necropsies performed on stranded pinnipeds constitute a strategy in wildlife research, giving information about the direct causes, predisposing factors, or possible threats that determine the mortality of a population or susceptibility to certain diseases [1-10].

Parasitological approaches provide a clue on feeding habits for each species or age class depending on the preys it consumes. Overall, it is known that most parasitic species affecting pinnipeds are heteroxenic having fish as intermediate or paratenic hosts; in pups, lactogenic route constitutes an additional source of gastrointestinal parasites [11, 12].

Among pinnipeds, the South American fur seal (SAFS), Arctocephalus australis (Zimmermann, 1783) (Carnivora: Otariidae), is a species distributed in several countries of
South America [13]. The largest breeding colony (estimated population: 300,000 animals [14]) is harboured in Uruguay, and it is distributed in different islands, sharing the same settlement with the South American sea lion (Otaria flavescens Shaw, 1800) [15]. Females give birth to one pup per season, and lactation typically ranges from 8 to 12 months, though it can occasionally extend further $[16,17]$.

Pathological studies on the species performed in Isla Guafo (Chile) have revealed that mortality in pups from 1 to 3 months old was mainly due to enteritis, and to a lesser extent to starvation, drowning, trauma, and premature births [18]. In other otariid species, main findings on necropsies or death causes in pups are parasitic enteritis, starvation, premature births, and trauma [19-21]. Morgades et al. [12] have found that in SAFS pups intensity of infestation by Uncinaria spp. was considerably lower than in South American sea lion (O. flavescens).

From 2001 to 2010, systematic necropsies on SAFS were conducted from stranded dead animals found on the Atlantic 
coast of Uruguay. The objective of the present work was to describe the main pathological and parasitological findings and possible causes of death in SAFS pups in Uruguayan colonies. This information constitutes a basic approach about pup's health status and the first record of necropsies findings during the first year of life in the species.

\section{Materials and Methods}

A total of 105 SAFS pup carcasses were collected from beaches at Cabo Polonio ( $34^{\circ} 24^{\prime} 01^{\prime \prime} \mathrm{S}, 53^{\circ} 46^{\prime} 06^{\prime \prime} \mathrm{W}$, Rocha) and Isla de Lobos $\left(35^{\circ} 01^{\prime} 38^{\prime \prime} \mathrm{S}, 54^{\circ} 52^{\prime} 55^{\prime \prime} \mathrm{W}\right.$, Maldonado) or provided by rehabilitation centers between 2001 and 2010 . Necropsies were performed using conventional methods [22]. Pups were classified by their degree of decomposition (DD) on a subjective scale ( $1=$ fresh to $4=$ advanced decomposition) as described previously [23]. Animals with DD4 were only used for body morphometry and parasitological studies.

Age was estimated according to body length (BL) [16], measured in a straight line from tip of nose to tip of tail, and according to sampling date considering birth date as December 15th where a peak of births occurs [24]. Body condition (BC) was estimated by measuring the blubber thickness at the level of xiphoid process and considered poor $(\mathrm{BC} 1)$ from 0 to $0.5 \mathrm{~cm}$; regular $(\mathrm{BC} 2)$ from 0.6 to $1.5 \mathrm{~cm}$; good (BC3) from 1.6 to $3.0 \mathrm{~cm}$.

Stomach content and parasitological studies of the digestive tract were conducted following the methodology described by Morgades et al. [12]. In brief, the stomach, small and large intestine were dissected, measured (total length) and analyzed separately; the small intestine was also divided into three thirds to facilitate parasitological examination. The intestinal wall was opened and scraped with forceps, washed with tap water, and processed in sedimentation cups; once clear sediment was obtained, it was observed under stereoscopic magnifying glass. The respiratory tract (trachea, bronchi, and lungs) and nostrils were analyzed for pathological, bacteriological, and parasitological studies. Parasites samples were conserved in $70 \%$ alcohol in the collection of the Parasitology Department (Veterinary Faculty, University of Uruguay). Pooled samples of lung and mediastinal lymph node of each animal were cultured in Stonebrink and Lowenstein-Jensen media for Mycobacterium pinnipedii isolation.

Animals were grouped in age ranges from one to three months according to the number of animals necropsied in each period and were evaluated in relation to BC, parasitological and pathological findings. Pups body condition was analyzed grouping animals from 0 to 6 months and from 7 to 18 months for good $\mathrm{BC}$ (BC 2 and 3 together) and poor $\mathrm{BC}(\mathrm{BC} 1)$; comparisons were tested using Fisher's test (Instat software; significant $P<0.05)$.

\section{Results}

3.1. Age and Body Condition. Animals were aged between 0 and 18 months, and the ratio of males and females was similar for most age groups (Table 1).

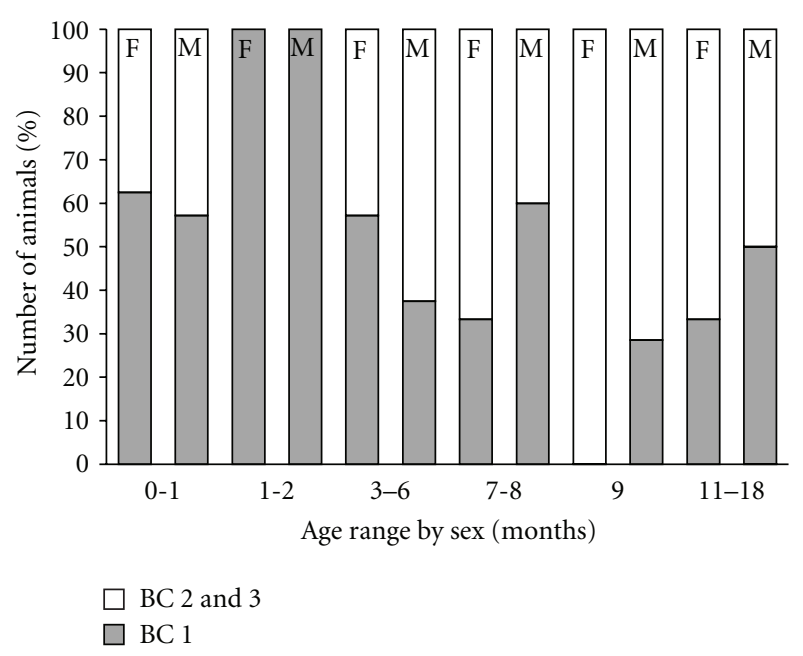

FIGURE 1: A. australis pup body condition (BC) by sex according to estimated age range $(\mathrm{M}=$ males; $\mathrm{F}=$ females $)$.

TABle 1: Number of $A$. australis pups, males and female, according to age range.

\begin{tabular}{lcc}
\hline Estimated age in months & No. of males & No. of females \\
\hline 0 to 1 & 14 & 16 \\
2 to 3 & 2 & 8 \\
4 to 6 & 6 & 4 \\
7 to 8 & 5 & 4 \\
9 to 10 & 20 & 10 \\
11 to 13 & 5 & 2 \\
16 to 18 & 4 & 4 \\
\hline
\end{tabular}

Most pups from 0 to 6 months old (64.4\%) were in bad condition, while most animals older than 7 months (79.7\%) had regular to good $\mathrm{BC}(P<0.0001)$ (Figure 1$)$. In the first 6 months of age, $55 \%$ of males and $72 \%$ of females were included in BC1. From 7 to 18 months, $37.9 \%$ of males and $5.3 \%$ of females presented $\mathrm{BC} 1$, with significant differences between sexes $(P=0.0200)$. Females maintained the differences in $\mathrm{BC}$ being the younger ones in $\mathrm{BC} 1(P<$ $0.0001)$, whereas in males there was no significant association between age and $\mathrm{BC}(P=0.2600)$.

Animals with poor $\mathrm{BC}(\mathrm{BC} 1)$ showed no pericardial or kidney external fat, while animals with moderate to good $\mathrm{BC}$ (BC2 and BC3) presented scarce or abundant fat surrounding these organs $(P<0.0001)$.

3.2. Parasitological Findings. Gastrointestinal parasites species varied according to pup's age. Uncinaria spp. (Nematoda) was found in pups up to 6 months old (Figure 2(a)). In a single female of approximately one month old, a large number (number not determined) of these parasites were located mainly in the first third of the small intestine. Gastrointestinal parasites (Acanthocephala and Nematoda) with indirect cycle were present in animals older than 6 months of age including Corynosoma spp., Contracaecum spp., and Tetrabothriidae; Strongyloides sp. were found 


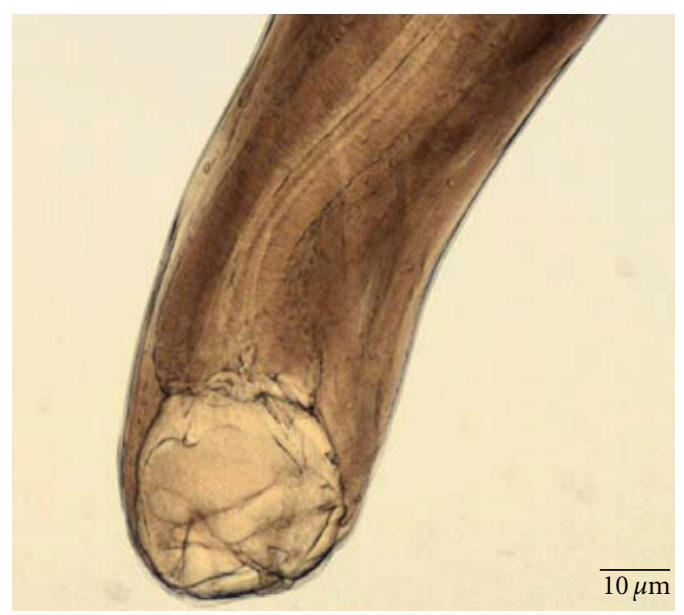

(a)

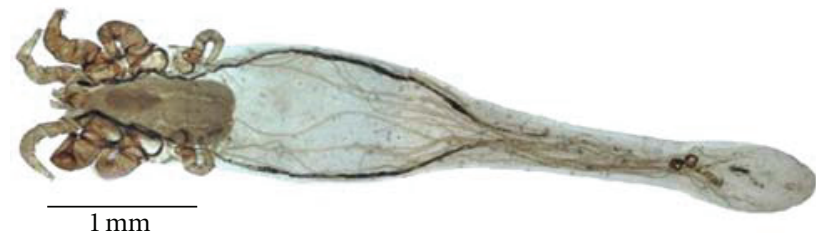

(c)

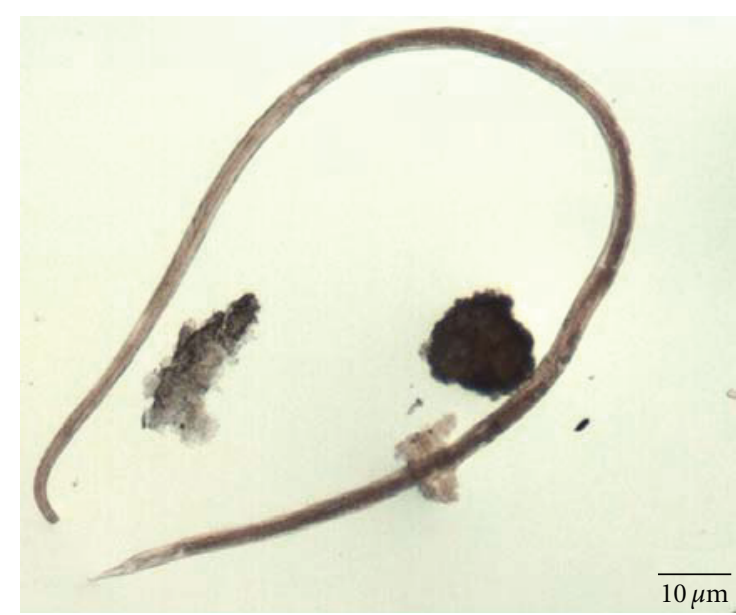

(b)

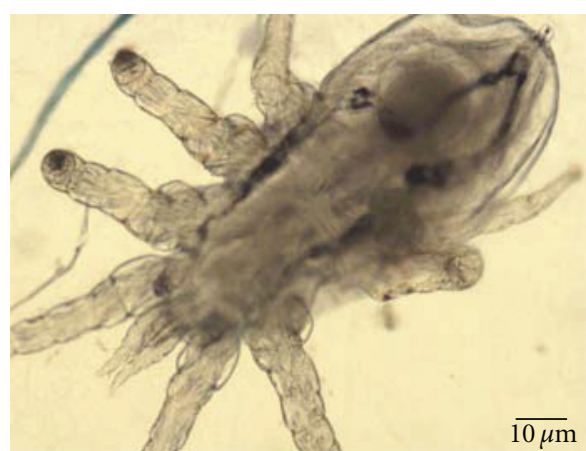

(d)

FIgure 2: Parasites found in SAFS pups. (a) Uncinaria spp. (bar, $10 \mu \mathrm{m}$ ); (b) Strongyloides spp. (bar, $10 \mu \mathrm{m}$ ); (c) O. attenuata, panoramic view (mosaic construction) (bar, $1 \mathrm{~mm}$ ); (d) Orthohalarachne diminuta (bar, $10 \mu \mathrm{m}$ ).

in the small and large intestine of three juvenile seals (Figure 2(b)) [12]. Mites (Orthohalarachne spp.) were obtained from pups of all ages; O. attenuata specimens were located in the nasopharynx (Figure 2(c)), while O. diminuta were present in the trachea and bronchi (Figure 2(d)) without gross lesions at sites of localization. Lice and nits (Proechinophthirus zumpti) were located in the face area near the eyes or in the neck in pups between 1 and 6 months of age.

3.3. Gross Pathological Findings. The gross lesions most frequently found were trauma located in the head, neck and chest; these injuries included bruising, bleeding, and torn muscles of the neck, region and head (Figure 3). Other traumatic lesions included head and neck abscesses, fractured skull, cervical spine and tracheal wall rupture, bleeding in the esophageal wall, dissection of thyroid glands, rib fractures, and hemothorax. In the respiratory tract, congestion and foamy content in tracheal and bronchial lumen, pulmonary congestion, emphysema, and in some animals lung hemorrhage was found (Figure 4). Trauma was found in $36.8 \%$ of pups in the first month of life, and the highest percentages were recorded for 9-months-old pups (both sexes: 66.6\%; males 60\%, females 75\%) (Figure 5).
There was no significant association between frequency of trauma and sex $(P=1.0000)$. In these traumatized specimens, gastrointestinal lesions (congestion and bleeding in stomach and intestinal mucosa) were also recorded as incidental findings. Lesions related to parasite infections were scarce; only one female pup of around one month old heavily infected with Uncinaria spp. presented extensive punctate hemorrhages in the intestinal wall, pale muscle mass, and poor body condition (BC1); in other animals with lower parasite load, there were focal areas of congestion and hemorrhage in the intestinal mucosa. No macroscopic lesions were observed in binding sites of the other helminths.

Other macroscopic lesions included gastric hemorrhages $(n=6)$; small intestine with focal and diffuse hemorrhages $(n=26)$ (Figure 7) and intussusception $(n=1)$; hemorrhages in large intestine $(n=10)$; lungs congestion $(n=17)$, emphysema $(n=5)$, edema $(n=7)$, and hemorrhages $(n=$ 9) (Figure 5); fatty degeneration $(n=1)$ and focal hepatitis $(n=6)$; skin ulcers $(n=2)$; in few cases, hemoperitoneum $(n=2)$, peritonitis $(n=2)$, and enlargement of mesenteric lymph node with renal abscess and purulent cystitis $(n=1)$ were found.

Lung lesions were frequent in those animals with severe trauma, but also in pups with undetermined cause of death. M. pinnipedii was isolated from pooled samples of lung 


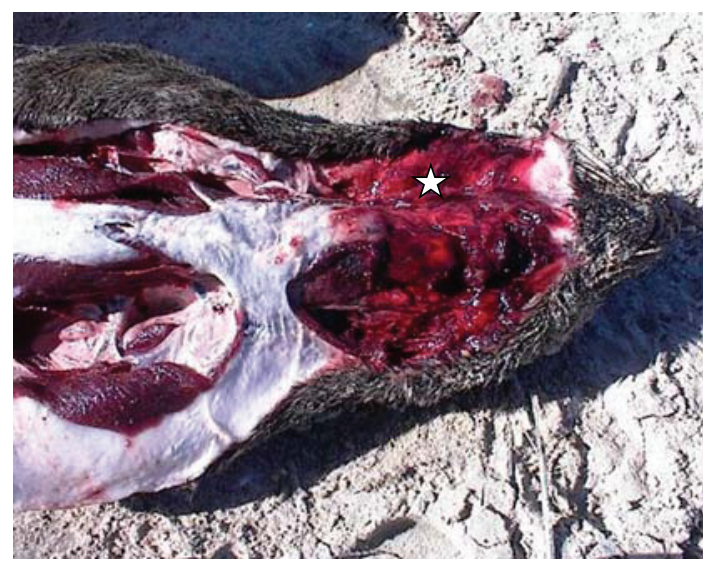

Figure 3: Bruising, bleeding, and torn muscles of the ventral neck region (white star).

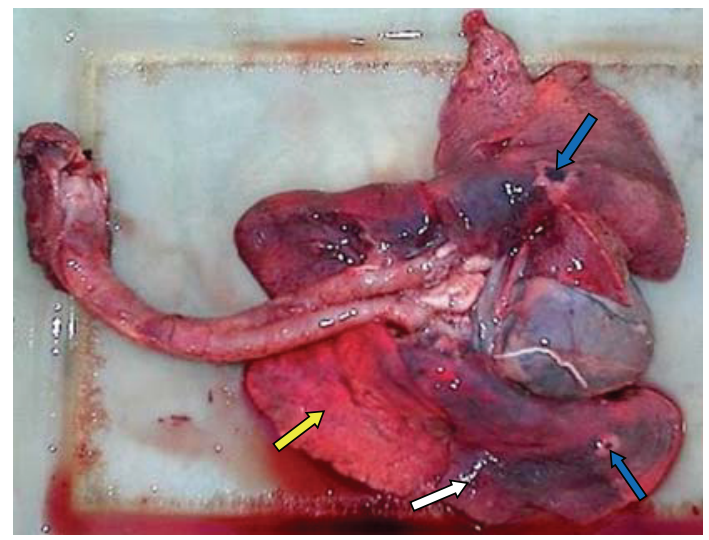

Figure 4: Respiratory tract from a SAFS pup. Pulmonary congestion (white arrow), emphysema (yellow arrow), and hemorrhage (blue arrow).

and mediastinal lymph nodes $(n=9)$ without gross pathological lesions.

In the first six months of age, stomachs were empty or contained milk. In a 6 months-old-female, fish remnants were found, while older pups contained fishes, crustaceans (unidentified shrimps and crabs), algae, stones, and foreign bodies (nylon, plastic, etc.).

\section{Discussion and Conclusions}

Data reported herein covers almost 10 years of field and laboratory work with seals in Uruguay and is the first approach to determine the most frequent death causes of $A$. australis pups in Uruguayan colonies.

Starvation was the most important cause of death in pups from 1 to 6 months old. This is consistent with the higher mortality in the first 3 months in animals with a lower growth rate related to extensive foraging trips of lactating females reported by Franco-Trecu [25] as well as reports in other pinniped species $[26,27]$.

Traumatic lesions were recorded in two different stages, one during the period of births (December) and the other

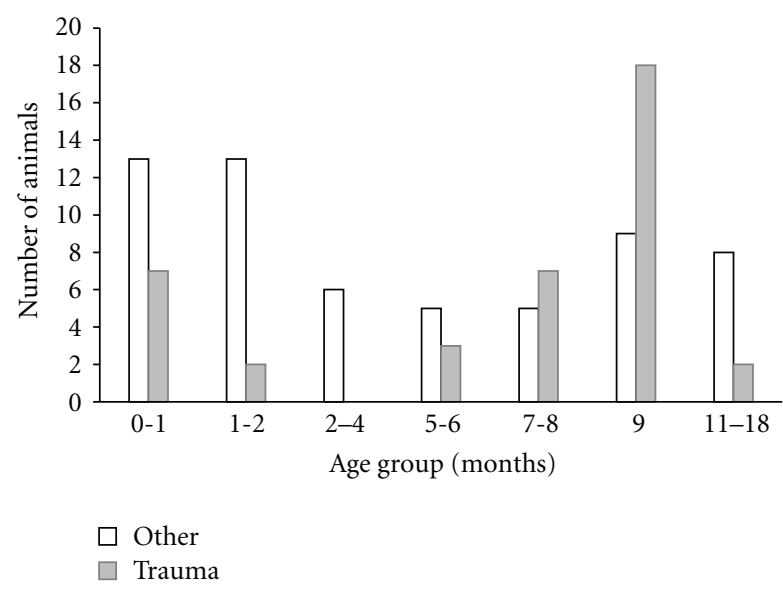

FIGURE 5: Number of pups with traumatic injuries and other causes of death in different age ranges.

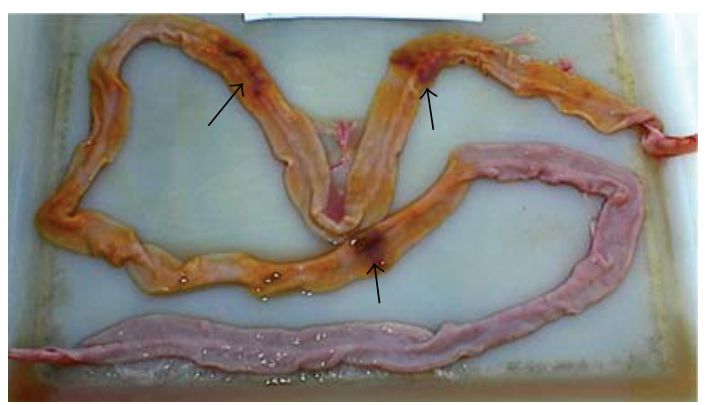

FIGURE 6: Small intestine from an 8-month-old SAFS pup. Several focal hemorrhages in the first third of the small intestine (black arrows).

around weaning (September). During the period of births and perinatal stages, there is an intense aggressiveness of females with her young cub against other pups (V. Franco, pers. com.), sometimes related to allosuckling [25], while in other cases they exert violent responses to other pups without any evident reason. High pup mortality was found in the intermediate weeks of the breeding season, when high levels of aggression would be associated with high population densities [25]. This phenomenon was also observed in SAFS from Peruvian colonies $[28,29]$ and in the Antarctic fur seals (A. gazella) [26] associated to density-dependent factors. During the weaning period (September), most pups had a good body condition and death was associated with severe trauma presumably caused by male juvenile South American sea lions, and other animals (groups of dogs in Cabo Polonio beaches were recorded hunting fur seal pups in the water, see Figure 7). During the breeding season, there are also reports about attacks on SAFS pups by juvenile male sea lions (Figure 8), frequently observed by other researchers and seal keepers at Isla de Lobos (V. Franco and R. Frau, pers. com.) and Cabo Polonio [30]. In the Peruvian SAFS colonies, Harcourt [28] observed predation of SAFS pups by adult sea lions and very low defense response of their mothers, while in Uruguay (Cabo Polonio) females exhibit greater behavior of defense and attempts to recover their pups [31]. 


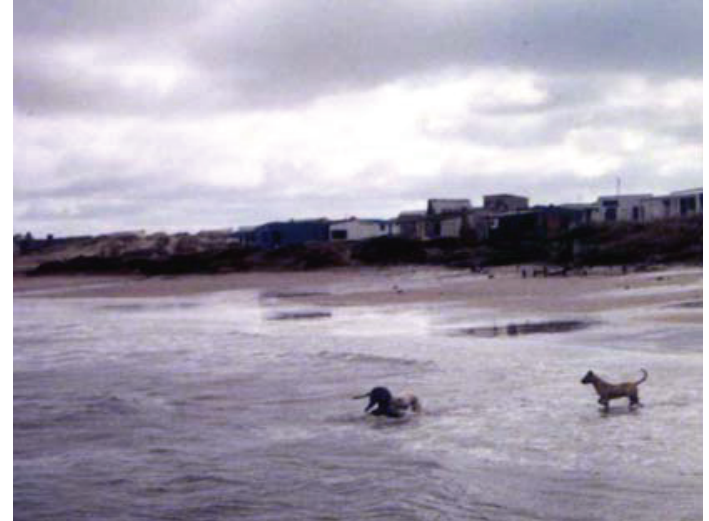

Figure 7: Group of dogs at Cabo Polonio south beach catching a SAFS pup.

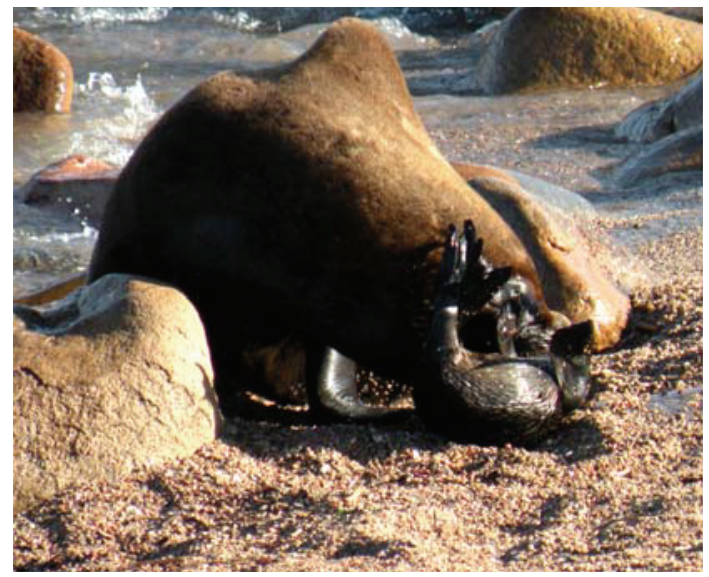

FIgURE 8: Juvenile male O. flavescens attacking a SAFS pup, Isla de Lobos, Uruguay.

According to former reports [13, 16], weaning begins in August, when pups are about 8 months old. However, the finding of fish, crustaceans, and other solid materials in stomach contents of pups 6-7 months old indicates that they do catch small preys probably as part of a learning process, as described for other pinnipeds [32]. This fact is further supported since some pups (from 6 months and older) harbored parasites with indirect cycle.

Parasitological findings of this study are based on previous reports [12]. It complements the record of Uncinaria spp. on specimens in the first month after birth associated with direct transmission through milk [1, 11, 33]. Overall, parasitic infections in SAFS pups from Uruguayan colonies were not linked to serious gastrointestinal disease or associated to systemic pathologies (anemia, sepsis) which could be the cause of death. Extensive intestinal lesions by Uncinaria spp. as reported by Seguel et al. [18] and Spraker et al. [19] were observed only in one specimen. The presence of Strongyloides spp., a parasite described only recently for pinnipeds [12], posits a new question on the source of the infection and the biological cycle it can develop in SAFS. Mites in the respiratory tract were found extensively in newborn pups and older indicating early transmission, probably by aerosols. Although no macroscopic lesions were observed, Seguel et al. [18] have reported a mild inflammatory reaction in the nasopharynx. However, it is likely that the stimulus caused during their movement is enough to develop coughing responses, which are common in pups and adult animals, at any time of year and any time of day or night (H. Katz, pers. obs.). Probably this mechanism facilitates spread through sprays that occur during coughing [34] or by nasonasal contact, which is so characteristic of pinnipeds. In northern fur seals (C. ursinus), heavy mite infestations may cause difficulty breathing, emphysema in or predisposition to more severe diseases [32]; so we cannot rule out the occurrence of similar conditions in SAFS pups. Lice have been found in low numbers and few specimens, so their ability to infect and spread is considered to be limited and its pathogenic effect is of low magnitude.

Lesions in the stomach and small intestine were not associated with severe intestinal infections or parasites that might be the cause of death, as many of these lesions were found in specimens older than 6 months (Figure 6) without Uncinaria spp., with good body condition that died by acute trauma. According to our necropsy findings, neither drowning due to summer storms, parasitic diseases [35], nor the enteritis/bacteremia syndrome described in fur seals and sea lions in other populations $[18,21]$ would be affecting negatively the SAFS colonies in Uruguay.

Alterations in the respiratory system were common in all necropsied specimens, particularly those who died from severe trauma. However, the presence of mucus in the tracheal, bronchial, and bronchiolar lumen would indicate an underlying inflammatory process as described in pups from Guafo Island of unknown aetiology [18]. Furthermore, isolation of $M$. pinnipedii in pups without gross lesions indicates that the bacterium is acquired in early stages of their life. Serological studies have reported exposure to influenza $A$ and B viruses in SAFS pups in Uruguay [36], but it is unknown if it could act as a primary or predisposing cause of respiratory infections. In the New Zealand sea lions, pulmonary and systemic infections by Klebsiella pneumoniae have contributed to significant pup mortality [21], but it is unknown if this bacteria could be affecting SAFS.

SAFS colonies in Uruguay do not show, apparently, diseases or conditions that may put their population in risk, but the absence of epidemiological studies prevents us from knowing whether pathogens are circulating in native colonies. The coastal ecosystems of Cabo Polonio, Isla de Lobos, and other pinnipeds settlement areas are strongly influenced by anthropogenic factors (sewage from cities and small towns near seal colonies, presence of domestic animals and plague species) that could promote the development of different infectious or parasitic diseases diagnosed in other marine mammal populations $[3,6,37-40]$. In this context, an initial serological survey conducted in cats from Isla de Lobos $(n=3)$ resulted in high antibody titers against Toxoplasma spp., consistent with active infection (H. Katz, unpublished data), being a potential risk of infection for pinnipeds and other marine mammals.

This is the first report of necropsy findings in SAFS pups colonies of Uruguay. While the findings in the first three 
months of life are similar to reports of other pinniped colonies, traumatic lesions are described for the first time as the most important cause of death in individuals older than 7 months. It would be important to perform long-term and systematic studies, including other diagnosis methods for assessing the health status of pinniped colonies in Uruguay.

\section{Conflict of Interests}

The authors declare that they have no conflict of interests.

\section{Acknowledgments}

The authors thank the National Direction of Aquatic Resources, Ministry of Livestock, Agriculture and Fisheries (DINARA-MGAP) for collecting permits granted; seal keepers who always help in animal handling (M. Casella, M. Pereira, L. Olivera, and N. Veiga); NGOs Socobioma (Dr. L. Casas) and Profauma for providing animals from rehabilitation centers; they are gratefully to workmates and teachers of the Veterinary and Science Faculties: Graciela Pedrana, Carlos De Souza, Antonio Moraña, Oscar Correa, José Manuel Venzal, Francisco Gutierrez, and Ma Laura Bertalmio and biologists Valentina Franco, Federico Riet, Rosina Frau, who together have contributed greatly to carry out activities in Cabo Polonio and Isla de Lobos; Dr. Dinora Satragno for toxoplasmosis serological test in cats. Lic. Oscar F. Castro for constructive reading and comments of the early draft. This work was partially funded by CIDEC (Comisión de Investigación y Desarrollo Científico, Universidad de la República, Uruguay).

\section{References}

[1] O. W. Olsen and E. T. Lyons, "Life Cycle of the Hookworm, Uncinaria lucasi Stiles, of the Northern Fur Seals Callorhinus ursinus, on the Pribilof Island in the Bering Sea," The Journal of Parasitology, vol. 48, pp. 42-43, 1962.

[2] T. Barrett, M. Blixenkrone-Møller, G. Di Guardo et al., "Morbilliviruses in aquatic mammals: report on round table discussion," Veterinary Microbiology, vol. 44, no. 2-4, pp. 261265, 1995.

[3] F. M. D. Gulland, M. Koski, L. J. Lowenstine, A. Colagross, L. Morgan, and T. Spraker, "Leptospirosis in California sea lions (Zalophus californianus) stranded along the central California coast, 1981-1994," Journal of Wildlife Diseases, vol. 32, no. 4, pp. 572-580, 1996.

[4] M. A. Stamper, F. M. D. Gulland, and T. Spraker, "Leptospirosis in rehabilitated Pacific harbor seals from California," Journal of Wildlife Diseases, vol. 34, no. 2, pp. 407-410, 1998.

[5] M. A. Miller, P. R. Crosbie, K. Sverlow et al., "Isolation and characterization of Sarcocystis from brain tissue of a freeliving southern sea otter (Enhydra lutris nereis) with fatal meningoencephalitis," Parasitology Research, vol. 87, no. 3, pp. 252-257, 2001.

[6] M. A. Miller, I. A. Gardner, C. Kreuder et al., "Coastal freshwater runoff is a risk factor for Toxoplasma gondii infection of southern sea otters (Enhydra lutris nereis)," International Journal for Parasitology, vol. 32, no. 8, pp. 997-1006, 2002.
[7] J. P. Dubey, R. Zarnke, N. J. Thomas et al., “Toxoplasma gondii, Neospora caninum, Sarcocystis neurona, and Sarcocystis canislike infections in marine mammals," Veterinary Parasitology, vol. 116, no. 4, pp. 275-296, 2003.

[8] L. N. Measures, J. P. Dubey, P. Labelle, and D. Martineau, "Seroprevalence of Toxoplasma gondii in Canadian pinnipeds," Journal of Wildlife Diseases, vol. 40, no. 2, pp. 294-300, 2004.

[9] U. Siebert, P. Wohlsein, K. Lehnert, and W. Baumgärtner, "Pathological findings in harbour seals (Phoca vitulina): 19962005," Journal of Comparative Pathology, vol. 137, no. 1, pp. $47-58,2007$.

[10] T. Goldstein, J. A. K. Mazet, T. S. Zabka et al., "Novel symptomatology and changing epidemiology of domoic acid toxicosis in California sea lions (Zalophus californianus): an increasing risk to marine mammal health," Proceedings of the Royal Society B, vol. 275, no. 1632, pp. 267-276, 2008.

[11] E. T. Lyons, R. L. DeLong, S. R. Melin, and S. C. Tolliver, "Uncinariasis in northern fur seal and California sea lion pups from California," Journal of Wildlife Diseases, vol. 33, no. 4, pp. 848-852, 1997.

[12] D. Morgades, H. Katz, and O. Castro, "Fauna parasitaria del lobo fino Arctocephalus australis y del león marino Otaria flavescens (Mammalia, Otariidae) en la costa uruguaya. Bases para la conservación y el manejo de la costa atlántica uruguaya," in Vida Silvestre, R. Menafra, L. Rodríguez-Gallego, F. Scarabino, and D. Conde, Eds., pp. 89-96, Montevideo, Uruguay, 2006.

[13] R. Vaz Ferreira and A. Ponce de León, "South American fur seal, Arctocephalus australis, in Uruguay. Status, biology and ecology of fur seals," in National Oceanic and Atmospheric Administration (NOAA). Technical Report. National Marine Fisheries Service (NMFS), J. P. Croxall and R. L. Gentry, Eds., vol. 51, pp. 29-32, Montevideo, Uruguay, 1987.

[14] E. Páez, "Utilización de Boostrap y análisis de poder en estimaciones de abundancia de cachorros de Arctocephalus australis," in Sinopsis de la Biología y Ecología de las Poblaciones de Lobos Finos y Leones Marinos de Uruguay, M. Rey and F. Amestoy, Eds., Pautas Para su Manejo y Administración. Proyecto URU/92/003, pp. 55-70, INAPE, Montevideo, Uruguay, 2000.

[15] R. Vaz Ferreira, Arctocephalus australis Zimmermann, South American fur seal. Food and Agriculture Organization, Fisheries Service, no. 5. vol. 4, (UN/FAO//ACMRR Ad Hoc III/20), 497.508, 1982.

[16] A. Ponce de León, Crecimiento Intrauterino y Postnatal del Lobo de dos Pelos Sudamericano, Arctocephalus australis (Zimmerman, 1783), en Islas de Uruguay. Actas del VIII Simposio Latinoamericano de Oceaografía Biológica, Montevideo, Uruguay, 1983.

[17] A. Ponce de León, Lactancia y Composición Cuantitativa de Leche de Lobo Fino Sudamericano Arctocephalus australis (Zimmerman, 1783), ILPE. Anales, Montevideo, Uruguay, 1984.

[18] M. Seguel, E. Paredes, H. Pavés et al., "Pathological findings in South American fur seal pups (Arctocephalus australis gracilis) found dead at guafo Island, Chile," Journal of Comparative Pathology, vol. 145, no. 2-3, pp. 308-317, 2011.

[19] T. R. Spraker, R. L. DeLong, E. T. Lyons, and S. R. Melin, "Hookworm enteritis with bacteremia in California sea lion pups on San Miguel Island," Journal of Wildlife Diseases, vol. 43, no. 2, pp. 179-188, 2007.

[20] B. L. Chilvers, B. C. Robertson, I. S. Wilkinson, P. J. Duignan, and N. J. Gemmell, "Male harassment of female New Zealand sea lions, Phocarctos hookeri: mortality, injury, and harassment avoidance," Canadian Journal of Zoology, vol. 83, no. 5, pp. 642-648, 2005. 
[21] A. Castinel, P. J. Duignan, W. E. Pomroy et al., "Neonatal mortality in New Zealand sea lions (Phocarctos hookeri) at Sandy Bay, Enderby Island, Auckland Islands from 1998 to 2005," Journal of Wildlife Diseases, vol. 43, no. 3, pp. 461-474, 2007.

[22] L. Dierauf, Handbook of Marine Mammal Medicine: Health, Disease and Rehabilitation, C.R.C. Press, 1990.

[23] H. Katz, W. Pérez, A. Bielli, and R. Chavez, "Histomorphology of prepuberal ovaries in the South American fur seal (Arctocephalus australis Zimmerman, 1783)," Folia Morphologica, vol. 68 , no. 4, pp. 277-286, 2009.

[24] V. Franco Trecu, Comportamiento maternal y aspectos reproductivos de Arctocephalus australis en Isla de Lobos, Uruguay, Tesis de Grado. Facultad de Ciencias, Universidad de la República, Montevideo, Uruguay, 2005.

[25] V. Franco Trecu, Éxito de Crianza y Hábitos Alimenticios en Hembras del Lobo Fino Sudamericano (Arctocephalus australis) y su Relación Trófica con Hembras del León Marino Sudamericano (Otaria flavescens), Tesis de Maestría. PEDECIBA. Facultad de Ciencias, Universidad de la República., Montevideo, Uruguay, 2010.

[26] D. W. Doidge, J. P. Croxall, and J. R. Baker, "Density-dependent pup mortality in the Antarctic fur seal Arctocephalus gazella at South Georgia," Journal of Zoology, vol. 202, pp. 449460, 1984

[27] K. Reid and J. Forcada, "Causes of offspring mortality in the Antarctic fur seal, Arctocephalus gazella: the interaction of density dependence and ecosystem variability," Canadian Journal of Zoology, vol. 83, no. 4, pp. 604-609, 2005.

[28] R. Harcourt, "Factors affecting early mortality in the South American fur seal (Arctocephalus australis) in Peru: densityrelated effects and predation," Journal of Zoology, vol. 226, no. 2, pp. 259-270, 1992.

[29] P. Majluf, "Timing of births and juvenile mortality in the South American fur seal in Peru," Journal of Zoology, vol. 227, no. 3, pp. 367-383, 1992.

[30] M. H. Cassini, "Aggression between females o the Southern fur seal (Arctocephalus australis) in Uruguay," Mammal Review, vol. 31, no. 2, pp. 169-172, 2001.

[31] M. H. Cassini, "Inter-specific infanticide in South American otariids," Behaviour, vol. 135, no. 9-10, pp. 1005-1012, 1998.

[32] T. R. Loughlin, J. T. Sterling, R. L. Merrick, J. L. Sease, and A. E. York, "Diving behavior of immature Steiler sea lions (Eumetopias jubatus)," Fishery Bulletin, vol. 101, no. 3, pp. 566-582, 2003.

[33] E. T. Lyons, Biology of the hookworm, Uncinaria lucasi Stiles, 1901, in the northern fur seal, Callorhinus ursinus Linn. on the Pribilof Islands, Alaska [Ph.D. thesis], Colorado State University, Fort Collins, Colo, USA, 1963.

[34] K. C. Kim, V. L. Haas, and M. C. Keyes, "Populations, microhabitat preference and effects of infestation of two species of Orthohalarachne (Halarachnidae: Acarina) in the northern fur seal," Journal of wildlife diseases, vol. 16, no. 1, pp. 45-51, 1980.

[35] A. Ponce de León, “Taxonomía, sistemática y sinopsis de la biología y ecología de los pinipedios de Uruguay," in Sinopsis de la Biología y Ecología de las Poblaciones de Lobos Fnos y Ieones Marinos de Uruguay. Pautas Para su Manejo y Administración. Parte I. Biología de las Especies, M. Rey and F. Amestoy, Eds., p. 117, Montevideo, Uruguay, 2000.

[36] A. Blanc, D. Ruchansky, M. Clara, F. Achaval, A. Le Bas, and J. Arbiza, "Serologic evidence of influenza A and B viruses in South American fur seals (Arctocephalus australis)," Journal of Wildlife Diseases, vol. 45, no. 2, pp. 519-521, 2009.
[37] K. Acevedo-Whitehouse, H. De la Cueva, F. M. D. Gulland, D. Aurioles-Gamboa, F. Arellano-Carbajal, and F. SuarezGüemes, "Evidence of Leptospira interrogans infection in California sea lion pups from the Gulf of California," Journal of Wildlife Diseases, vol. 39, no. 1, pp. 145-151, 2003.

[38] L. N. Measures, J. P. Dubey, P. Labelle, and D. Martineau, "Seroprevalence of Toxoplasma gondii in Canadian pinnipeds," Journal of Wildlife Diseases, vol. 40, no. 2, pp. 294-300, 2004.

[39] D. Albareda, M. Uhart, L. Samartino et al., "Serological evidence of exposure to selected infectious agents in Otaria flavescens and Arctocephalus australis from Argentina," in Proceedings of the 55th Annual Meeting of the Wildlife Disease Association, University of Connecticut, USA, August 2006.

[40] D. Forman, N. West, J. Francis, and E. Guy, "The seroprevalence of Toxoplasma gondii in British marine mammals," Memorias do Instituto Oswaldo Cruz, vol. 104, no. 2, pp. 296298, 2009. 

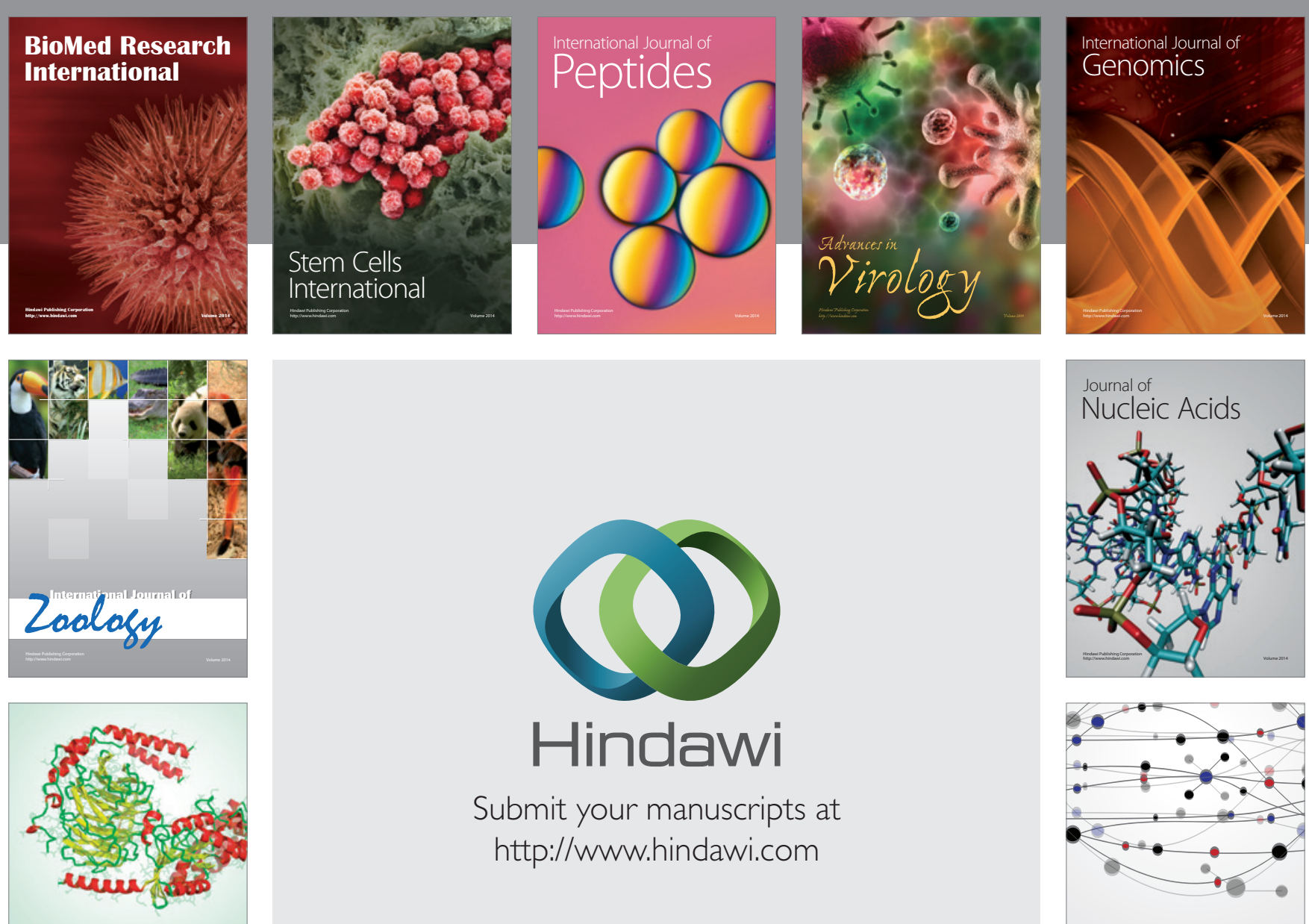

Submit your manuscripts at

http://www.hindawi.com

Signal ${ }^{\text {Jumal }}$ Transduction
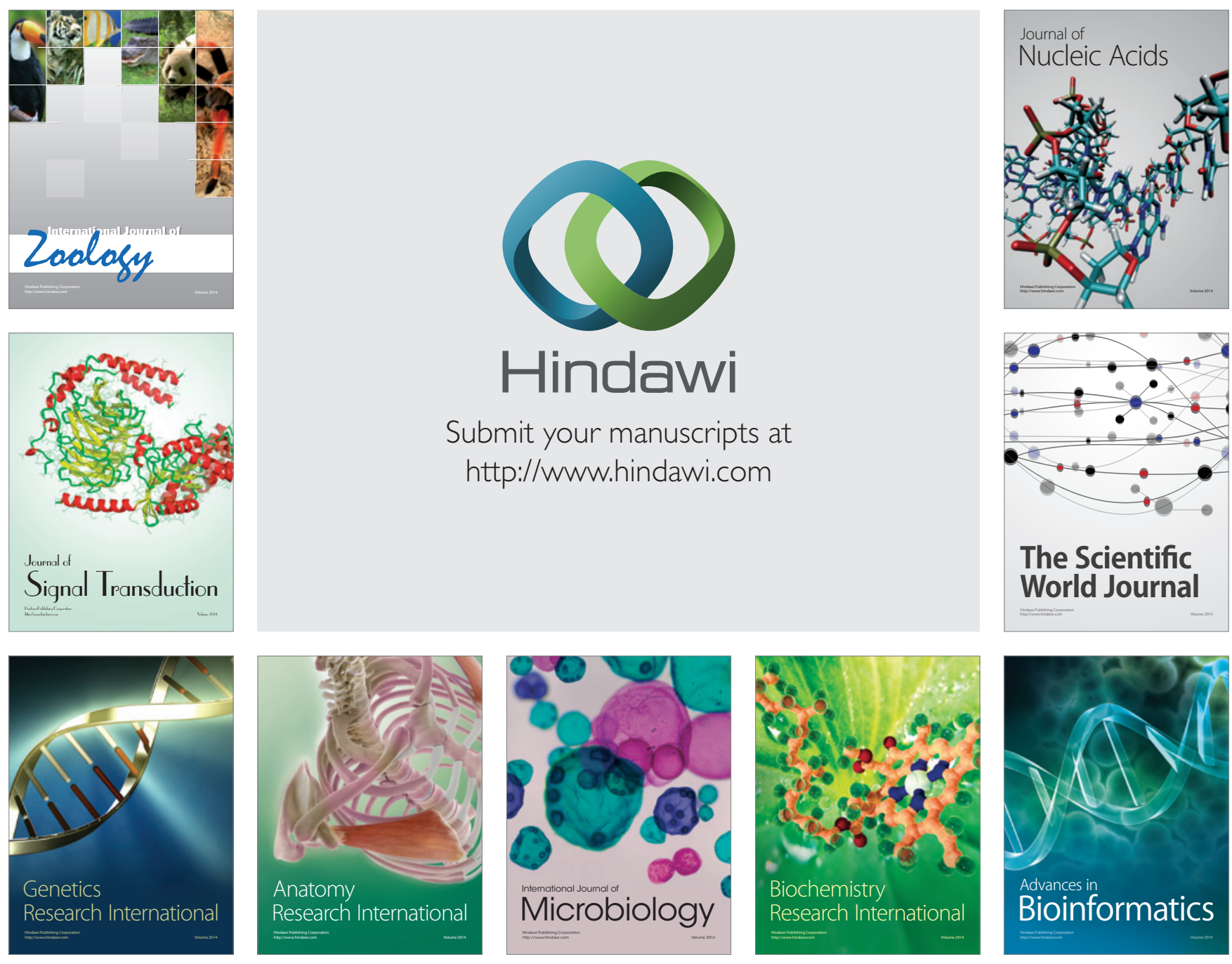

The Scientific World Journal
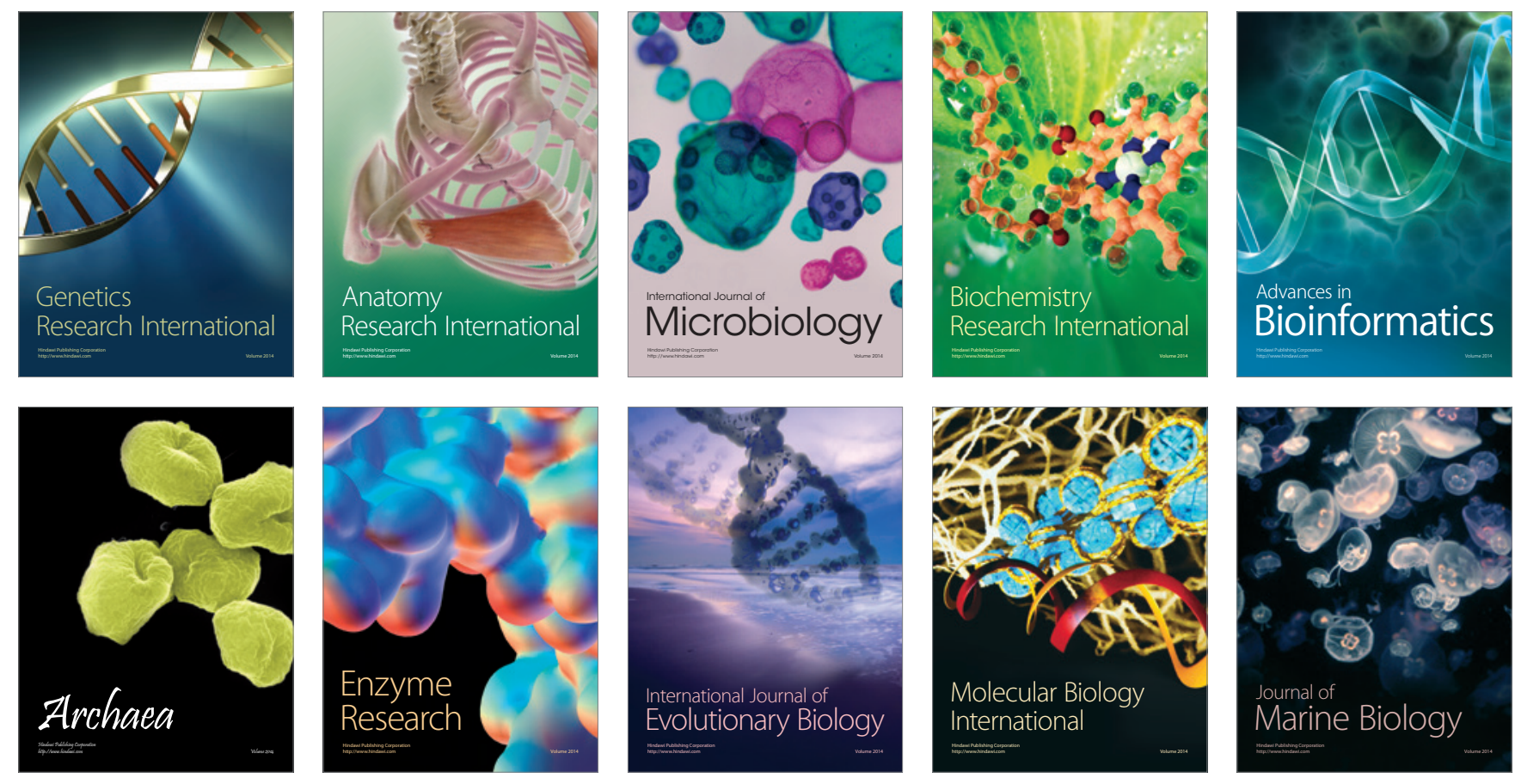